DE DE GRUYTER

OPEN

\title{
WHY SO MUCH SEXUAL VIOLENCE AGAINST WOMEN IN \\ GLOBALIZED INDIA?
}

\author{
HARASANKAR ADHIKARI \\ Monihar Co-operative Housing Society \\ Flat No.- 7/2. 1050/2, Survey Park \\ Kolkata-700075, West Bengal, India. \\ jaoya123@yahoo.co.in
}

\begin{abstract}
This paper attempts to discuss the causes of violence against women in India in relation to their body-revealing dress and conditional consent to sexual relations. Historically, women in Indian society have been victims of gender practices under the typical patriarchy. Culturally, women are treated as sex objects and their status is bounded within the periphery of feminine role-relations as housekeepers and pro-creators of generation. Women's education and participation in the workforce are not bringing with them the expected changes in gender stereotyped-ness. Even the work done on gender justice and women's human rights has failed to establish their status as anything more than sex objects. The rampant sexual violence against women is a reminder that the problem is deeply rooted in Indian society. In such a situation we may not be able to avoid considering the responsibility of women. Their bodyrevealing clothing and conditional consent to sexual relation are significant in
\end{abstract}


provoking men into treating them as sex objects. So we should think about how to bring about a change in gender practices and this should start in each and every family. The family as a correctional institution should teach its offspring about gender equality and their behavior and attitude towards gender should regard the physical and physiological differences between the sexes as minor. This might perhaps be a step towards reducing violence against women.

Keywords: body-revealing dress, gender practice, sexual relation, violence against women.

In the Rigveda and other scriptures we see that women held a place of high respect in Ancient India. But later on women lost their status and were relegated to the background because of social, political and economic changes (Goel 2004). Patriarchal politics restricted them to the confines of the house with many evil customs and rituals. Thus there was a prolonged history of women undergoing deprivation. But in modern, globalized India, statistics now show that there have been changes; we see a decline in sex-selective abortion, evidence of better health levels, a higher literacy rate, more work outside the home and increased political participation among women. On the other hand, we find that social evils such as dowry death, child marriage, domestic violence, rape, sexual harassment, and exploitation of women workers are rampant throughout India. Humiliation, rape, molestation, kidnapping, torture and the like have increased over the years (Singh and Choudhury 2012). So is this only the backdrop of the stereotyped attitudes towards women in our society? When the feminist movement and government development policymakers and implementation agencies attempt to address gender equity and women's empowerment, they somehow fail to look at the issues through a 
'sexuality lens' (Jolly, Cornwall and Hawkins 2013). Thus women's empowerment turns into sexual empowerment and this widens the scope of sexual exploitation and harassment of females. This paper attempts to discuss the causes of violence against women in relation to their body-revealing dress and conditional consent to sexual relations.

\section{The Issue of Women's Dress}

It is commonly considered that cultural practices construct women as sexual objects (Berger 1972; Fredrickson \& Roberts 1997; LeMoncheck 1984; Spitzack 1999). Objectifying images such as exposed body parts, seductive appearance and tantalizing behaviour in women project their sensuality and an eagerness to consent to all men's sexual advances at all times. Such a depiction of women has been increasing dramatically over the past decades and has become particularly prevalent in Indian society. This widespread sexual objectification of women transmits certain messages to men and influences expectations regarding the interaction between sexes. This objectifying representation undoubtedly operates to turn the female body into a willing target for male sexual desire (Spitzack 1999). Women wear body-revealing clothing for a variety of socially dictated reasons that are needed in order for them to be socially valued. It helps them to be considered attractive, both by themselves and by others and they do it to feel good about themselves. The primary reason for wearing such clothing is thus the social, interpersonal and personal advantage it confers in terms of attractiveness and desirability. However, men's attribution of motivation for this sexualized look is different, 
as they perceive it as conveying an interest in sex, temptation and seduction (Peter and Valkenburg 2007).

After all, body-revealing clothing may be a stimulus to men and the sexually objectifying representation of women has as its precise purpose the sexual excitement and stimulation of men. In the present social context, female beauty is constructed in sexual terms. In fact, sexualized representations of female beauty pervade almost every form of expression in the present day and the media worldwide is saturated with sexualized depictions of women in tight body-revealing clothing and with exposed body parts (Aubrey 2006; EngelnMaddox 2006). To be considered attractive in the present social prism women must conform to these dictates and adopt the sexualized look. In addition to this, the contemporary pressure coercing women into the sexualized look also includes the current objectifying fashion codes that have made body-revealing clothes into part of the standard female look to which all women are expected to aspire and adhere. Thus, modern-day fashion turns women into more of an object and less of a person in the social prism and valuation. At the very same time, it has made it almost impossible for them to avoid wearing this type of clothing. Women are valued primarily on the basis of their looks, since they lack tangible power of their own. Their sexualized appearance has become one of their very few assets in the contemporary social milieu (Fedrickson and Roberts 1997; LeMoncheck 1985; Muehlenkamp and Saris Baglama 2002). So there may indeed be a relation between provocative clothing and sexual assault.

\section{Conditional Consent to Sexual Relations}


The social value of women has been determined in terms of their value as sexual objects. In many cases, women of different age groups use this as a means to acquire benefits. Conditional consent to sexual relations is one example. This becomes a means of sexual exploitation when they fail to fulfill their promises after the sexual act. The law and order authorities take it for granted that the male partner should be punished for breaking an undertaking. But consent to sexual relations "is an act in which one person alters the normative relations in which others stand with respect to what they may do" (Kleinig 2001). That is, their rights, duties, obligations, privileges, and the like. It can transform a harmful action into a non-harmful action. It is sufficient to legitimize interaction for mutual benefit (Fletchen 1996). A person could choose to interact with others in a way that benefits them, yet is to their own detriment, so long as the choice is clearly voluntary. But if people typically consent only to those interactions that will improve their expected welfare and if people typically make fairly good judgments about such matters, then consensual interactions will leave both parties better off than they would otherwise be.

Voluntary co-operation may be explained in terms of an ethics of autonomy which also has two dimensions, positive and negative. Sexual relations are legitimate if the female's consent is given to endorse the positive dimension of autonomy, the notion that people should be permitted to seek emotional intimacy and sexual fulfillment with willing partners (Wertheimer 2003). So, women would not go against ethics merely for material gain - and primarily they should rely on their own sense of self-worth and self-respect. Their own potential should motivate them to seek to escape from male 
provocation. Otherwise, they would be abused and this would result in stigma for the remainder of their lives.

\section{Conclusion}

Feminism has broken the heterosexual association of female sexual awakening with dependency on a man. But women's sexual fulfillment without a man is unnatural according to antifeminist views (Adhikari 2013). So, in a patriarchal society where the women's body is considered to be a sex object, the sexual exploitation of women is widespread. Women's empowerment will not be served by an emphasis on sexuality. There should be some line of control to give them a respected status in which a sexualized look would not be the measure of their social value. The benefit at the individual level might be reduction in violence. This corrective action should begin in the family. Women's potential, skills and creativity would win them a position of respect. This would be the right step from which to move towards equity and justice. In any case, presentation of oneself as or self-use as a sex object will never facilitate gender equality.

\section{References}

Adhikari, Harasankar.2013. "Book Review: Vagina: A New Biography". Journal of International Women's Studies, 14(1): 354-355.

Aubrey, Jennifer Stevens. 2006. "Exposure to Sexually Objectifying Media and Body SelfPerceptions among College Women: An Examination of the Selective Exposure Hypothesis and the Role of Moderating Variables”. Sex Roles, 55:158-172.

Berger, John. 1972. Ways of Seeing. Harmondsworth: Penguin.

Engeln-Maddox, Renee. 2006. "Buying a Beauty Standard or Dreaming of a New Life? 
Expectations Associated with Media Ideals." Psychology of Women Quarterly, 30:258-266.

Fletchen, George P. 1996. Basic Concepts of Legal Thought. Oxford: Oxford University Press.

Fredrickson, Barbara L. \& Tomi-Ann Roberts, 1997. “Objectification Theory:

Toward Understanding Women's Lived Experiences and Mental Health

Risks." Psychology of Women Quarterly, 21:173-206.

Goel, Aruna.2004. Violence and Protective Measures for Women Development and

Empowerment. New Delhi: Deep \& Deep Publications.

Jolly, Susie; Cornwall, Andrea and Kate Hawkins. 2013. The Power of Pleasure: Sex, Pleasure and Empowerment. London: Zed Books.

Kleinig, John. 2001. "Consent” in Lawrence Becker and Charlotte Becker (Eds.)

Encyclopedia of Ethics. New York: Routledge.

LeMoncheck, Linda. (1985). Dehumanizing Women: Treating Persons as Sex Objects. Totowa, NJ: Rowman and Allanheld Publishers

Muehlenkamp, J. J. \& Saris-Baglama, R. N. 2002. "Self Objectification and its Consequences for College Women”. Psychology of Women Quarterly, 26:371-379.

Peter, Jochen \& Patti M. Valkenburg. 2007. “Adolescents' Exposure to a Sexualized Media Environment and Their Notions of Women as Sex Objects". Sex Roles, 56:381-395.

Singh, Awadhesh Kumar and Jayanta Choudhury. 2012. Violence against Women and Children - Issue and Concerns. New Delhi: Serial Publications.

Spitzack, Carole. 1990. Confessing Excitement: Women and the Politics of Body Reduction. Albany, NY: State University of New York Press.

Wertheimer, Alan. 2003. Consent to Sexual Relations. Cambridge: Cambridge University Press. 